\title{
Zróżnicowanie oceny sprawiedliwości wynagradzania w zależności od poziomu płac
}

\author{
Hanna Kinowska \\ Instytut Kapitału Ludzkiego, Kolegium Nauk o Przedsiębiorstwie, \\ Szkoła Główna Handlowa w Warszawie
}

\begin{abstract}
Sprawiedliwość jest kluczowym parametrem oceny poziomu wynagrodzenia. W polskiej literaturze brakuje analiz empirycznych analizujących istotę tego konstruktu. Główny celem przeprowadzonych badań była identyfikacja czynników wpływających na ocenę sprawiedliwości i ich zróżnicowania w zależności od poziomu płac. Wyniki analizy SEM-PLS na podstawie danych zebranych na reprezentatywnej próbie pracujących Polaków wykazały, że rodzaj czynników zmienia się przy miesięcznej kwocie wynagrodzenia 3500 PLN netto. Poniżej tej kwoty na ocenę sprawiedliwości wynagradzania wpływa troska przełożonego, system wynagradzania oraz przekonanie o słuszności różnicowania wynagrodzeń na podstawie nakładów, zadań i wyników. Powyżej wymienionej kwoty na tę ocenę również wpływa troska przełożonego oraz relacje w miejscu pracy.
\end{abstract}

Słowa kluczowe: wynagrodzenie, sprawiedliwość wynagradzania, poziom płac, zaangażowanie pracowników, przywództwo w organizacji

\section{Wprowadzenie}

System wynagradzania należy do czynników najsilniej wpływających na postawy pracowników. Jako składnik ogólnego systemu zarządzania kapitałem ludzkim powinien być on spójny z kulturą i strategią organizacji (Petersen, 2014). Ma kluczowe znaczenie dla satysfakcji pracowników, której brak skutkuje wyższą fluktuacją, absencją i gorszymi wynikami (Williams, McDaniel, Nguyen, 2006). Sprawiedliwość jest najbardziej istotnym parametrem oceny systemu wynagradzania. Poczucie niesprawiedliwości uruchamia tzw. zachowania kontrproduktywne 
w miejscu pracy (Colquitt i in., 2001) i wpływa na obniżenie gotowości pracowników do pomagania sobie nawzajem (Johnson, 2012).

Wzrost konkurencji oraz szybkie tempo zmian wymagają od firm poszukiwania innowacyjnych rozwiązań, prowadzących do oczekiwanych efektów biznesowych (Juchnowicz, Kinowska, 2017). Współczesne zarządzanie nadaje wynagrodzeniu szerokie znaczenie. Kompleksowe systemy wynagradzania wymagają wielowymiarowej oceny. Tworzą one okoliczności, które skłaniają do badań nad sprawiedliwości wynagrodzeń.

Celem artykułu jest eksploracja czynników wpływających na ocenę sprawiedliwości wynagradzania w zależności od jego poziomu. Model teoretyczny, opracowany na podstawie przeglądu literatury, zweryfikowano za pomocą analizy SEM-PLS. Eksploracja czynników wpływających na ocenę sprawiedliwości została przeprowadzona na podstawie wyników badań opinii pracujących Polaków na temat sprawiedliwości wynagradzania, przeprowadzonych w listopadzie $2017 \mathrm{r}$. w ramach grantu nr 2016/21/B/HS4/02992 pt. Sprawiedliwość wynagradzania, finansowanego przez Narodowe Centrum Nauki.

\section{Istota sprawiedliwości wynagradzania}

Problem sprawiedliwości pojawia się w filozofii od czasów Arystotelesa, który wprowadził podział na sprawiedliwość rozdzielczą i wyrównawczą (Arystoteles, 1956). Głównym kryterium sprawiedliwości rozdzielczej jest zasada proporcjonalności, z której wynika różne traktowanie osób nierównych sobie. Sprawiedliwość wyrównawcza pozwala postrzegać wynagrodzenie jako świadczenie wzajemne i ekwiwalentne względem pracy. Zgodnie z nią pracodawca ustala wynagrodzenie na podstawie wartości pracy świadczonej przez pracownika.

Tradycja filozoficzna nakazuje zastosowanie tych samych zasad postępowania w stosunku do osób wyłonionych na podstawie jednolitego kryterium (Wratny, 2015).

\section{Rola systemu wynagradzania}

W literaturze z zakresu zarządzania, badania nad sprawiedliwością wynagradzania są prowadzone w kontekście sprawiedliwości organizacyjnej (Petersen, 2014). Oznacza ona poczucie sprawiedliwości, dotyczące funkcjonowania organizacji w szerokim zakresie: podziału wynagrodzeń, możliwości rozwoju, awansowania, procedur obejmujących kryteria premiowe, awansowania, zwalniania oraz interakcji społecznych, czyli zasady komunikacji, informacji zwrotnych itp. (Turek, 2011). 
Historycznie pierwszą składową sprawiedliwości organizacyjnej stanowi sprawiedliwość dystrybutywna - ocena formułowana przez pracowników na podstawie porównania swojego wysiłku i korzyści otrzymywanymi w zamian z innymi (Adams, 1965).

Z czasem odkryto, że sprawiedliwość jest konstruktem znacznie bardziej złożonym niż proste porównanie rozkładu nakładów i wyników. Badacze zagadnienia zwrócili uwagę na konieczność zachowania sprawiedliwości procedur (Thibaut, Walker, 1975). Sprawiedliwy i bezstronny proces zwiększa prawdopodobieństwo zaakceptowania decyzji. Sformułowano następujące zasady, prowadzące do postrzegania sprawiedliwości procedur organizacyjnych: równość obowiązywania określonej procedury, brak stronniczości, precyzja informacji wpływających na wynik zastosowania procedury, uwzględnienie możliwości korekty błędnych lub niedokładnych decyzji, konsekwentne stosowanie standardów etycznych i moralnych oraz włączenie w proces osób, których decyzja dotyczy (Leventhal, 1980).

Przedstawione zasady stanowią podstawę do sformułowana pierwszej hipotezy badawczej:

- H1: Jawność, znajomość przez pracowników i konsekwencja w przestrzeganiu reguł systemu wynagradzania mają pozytywny wpływ na ocenę sprawiedliwości wynagradzania.

\section{Wpływ przełożonego}

Sprawiedliwość dystrybucyjna i proceduralna nie tłumaczą w pełni percepcji sprawiedliwości w organizacjach. Badacze dostrzegli konieczność uwzględnienia stosunków interpersonalnych (Bies, 2001). Ten wymiar został określony jako sprawiedliwość interakcyjna, podzielona na interpersonalną i informacyjną (Greenberg, 1993). Pierwsza z nich odnosi się do relacji z osobą przekazującą komunikat. Druga koncentruje się na ilości, precyzji i jakości informacji przekazywanych pracownikom. W miejscu pracy kluczową rolę w komunikacji odgrywa przełożony. Jego rola obejmuje również dostarczanie informacji o faktycznych procedurach decyzyjnych, dotyczących zasad wynagradzania. Kształtują one łączną ocenę sprawiedliwości organizacji, której testem jest postrzeganie wynagradzania jako sprawiedliwe (Mumford, Smith, 2012). Wyniki dostępnych badań empirycznych dotyczących wielowymiarowej oceny sprawiedliwości płac wskazują na kluczową rolę menedżera w jej kształtowaniu (Wu, Sturman, Wang, 2013).

Na podstawie dorobku literatury odnoszącej się do sprawiedliwości interpersonalnej i wymiany społecznej została sformułowana następna hipoteza:

- H2: Przekonanie o dbałości przełożonego o odpowiednie wynagrodzenie dla pracowników ma pozytywny wpływ na ocenę sprawiedliwości wynagradzania. 


\section{Znaczenie kryteriów}

Zgodnie z tradycją filozoficzną, sprawiedliwe różnicowanie wymaga wyboru cechy dywersyfikującej. Wybór ten odbywa się w odniesieniu się do skali wartości uzależnionych od norm etycznych. W ich kształtowaniu - chociaż żyjemy w erze globalizacji - nadal istotne znaczenie mają uwarunkowania lokalne. Analiza norm kształtujących przekonania polskich pracowników na temat sprawiedliwości wynagradzania została oparta na koncepcjach ekonomii i katolickiej nauki społecznej.

Godziwe wynagrodzenie pracowników jest przedmiotem zainteresowań społecznej odpowiedzialności biznesu (CSR), realizowanej na poziomie przedsiębiorstwa (Klimek, 2013). W tym ujęciu sprawiedliwość płacowych - i pozapłacowych - elementów motywacyjnych jest oceniana z ekonomicznego punktu widzenia.

Koncepcje sprawiedliwości ekonomii liberalnej wynikają $\mathrm{z}$ wiary $\mathrm{w}$ istnienie obiektywnych praw i mechanizmów rynkowych, prowadzących do harmonijnego przebiegu zjawisk społecznych (Hayek, 2011). W tym ujęciu poziom wynagrodzeń pracowników informuje ich, jaką pracę powinni wybrać, oraz pokazuje wartość określonego rodzaju wysiłku z punktu widzenia pracodawcy (Radzka, 2010). Pracodawcy, funkcjonujący $w$ realiach rynkowych, różnicują wynagrodzenia według wartości pracy poszczególnych osób. Jest ona określana na podstawie: koniecznych nakładów pracy, wymagań kompetencyjnych, złożoności zadań i odpowiedzialności oraz efektów pracy.

Ekwiwalentność sprawiedliwego wynagrodzenia w stosunku do wkładu jest elementem definicji sprawiedliwości obecnej w katolickiej nauce społecznej. Wprowadza ona rozróżnienie płacy sprawiedliwej i słusznej. Pierwsza z nich odpowiada wydajności pracy, druga - potrzebom pracownika (Wratny, 1995). Ekwiwalentność odnosi się do indywidualnej użyteczności pracy dla pracodawcy oznacza ona konieczność odniesienia płacy do wartości wytworzonego produktu.

Przedstawione argumenty są podstawą do sformułowania dwóch kolejnych hipotez badawczych:

- H3: Przekonanie, że w pracy najważniejsze jest wynagrodzenie, ma pozytywny wpływ na ocenę sprawiedliwości wynagradzania;

- H4: Przekonanie, że poziom wynagrodzeń powinien być uzależniony od: nakładów pracy, złożoności zadań i poziomu wyników ma pozytywny wpływ na ocenę sprawiedliwości wynagradzania. 


\section{Znaczenie relacji i rozwoju w ocenie sprawiedliwości wynagrodzeń}

Zaangażowanie pracowników jest kluczowym czynnikiem efektywności organizacji i jest m.in. powiązane z: lojalnością klientów, rentownością, produktywnością, wzrostem obrotów, bezpieczeństwem, brakiem absencji. Deficyt zaangażowania może mieć poważne konsekwencje praktyczne. Mimo to tematyka związków zaangażowania ze sprawiedliwością rzadko pojawia się w literaturze naukowej.

Zaangażowanie jest konceptualizowane na wiele sposobów (Hughes, Rog, 2008; Kinowska, 2009). Badacze zgadzają się, że obejmuje ono trzy - wzajemnie ze sobą powiązane - czynniki: kognitywny, emocjonalny i behawioralny (Shuck, Wollard, 2010). Stanowi rodzaj postawy wobec pracy (Juchnowicz, 2012). Wymaga posiadania wiedzy o przedmiocie postawy, pozytywnych lub negatywnych uczuć w stosunku do organizacji, a zwłaszcza do wartości i celów firmy, postępowania liderów, form i metod działania oraz określonego zachowania względem firmy. Zaangażowany pracownik wyróżnia się wysokim stopniem koncentracji na wykonywanej pracy, realizuje ją z pasją i entuzjazmem, ma pozytywny stosunek do organizacji i/lub pracy oraz wykazuje się wysokim stopniem aktywności zawodowej (Juchnowicz, 2012).

Związki między sprawiedliwością a zaangażowaniem pracowników wyjaśnia teoria wymiany społecznej. Organizacja i zatrudnieni pozostają we wzajemnej zależności. Relacje między nimi opierają się na lojalności i zaufaniu, jeśli obie strony respektują ustalone reguły (Cropanzano, Mitchell, 2005) i przestrzegają zasad sprawiedliwości (Colquitt i in., 2001).

Zaangażowanie wymaga specyficznego podejścia do motywowania. Wymaga wyznaczania celów korzystnych dla obu stron, stworzenia warunków, w których praca będzie wyzwaniem i źródłem satysfakcji oraz korzystania z kompleksowego instrumentarium motywacyjnego, w którego ramach bodźce są dopasowane do indywidualnych potrzeb pracowników (Juchnowicz, 2012).

Potrzeby są istotą nadrzędnej zasady sprawiedliwości, wynikającej z katolickiej nauki społecznej. Zgodnie z nią osoba pracownika ma pierwszeństwo przed pracą (Wratny, 1995). Dlatego wynagrodzenie powinno umożliwiać zaspokojenie potrzeb pracownika i jego rodziny oraz zapewnić środki niezbędne do egzystencji i rozwoju.

Przedstawione argumenty stanowiły podstawę do sformułowania następującej hipotezy:

- H5: Zaangażowanie i przekonanie, że w pracy istotne są relacje i możliwość rozwoju, mają pozytywny wpływ na ocenę wynagrodzenia. 


\section{Wpływ poziomu wynagrodzenia}

Prowadząc badania nad sprawiedliwością wynagradzania, nie można abstrahować od znaczenia poziomu płac. Związek między poziomem wynagrodzenia a oceną jego sprawiedliwości jest intuicyjny, ale mimo to słabo zbadany. Wyniki badań potwierdzają istotność statystyczną, ale stosunkowo niską siłę związku (Tekleab, Bartol, Liu, 2005).

Wpływ wynagrodzenia na ocenę sprawiedliwości jest zróżnicowany w zależności od poziomu płacy. Osoby z niższymi poziomami dochodów w większym stopniu opierają ich ocenę na porównaniach ze współpracownikami (Card i in., 2012). Dlatego można założyć, że poziom płacy będzie miał wpływ na znaczenie i siłę oddziaływania poszczególnych czynników kształtujących ocenę sprawiedliwości wynagrodzenia.

\section{Model oceny sprawiedliwości wynagradzania}

Hipotetyczne zależności między zmiennymi zostały przedstawione na rysunku 1.

Rysunek 1. Hipotetyczne zależności w badanym modelu

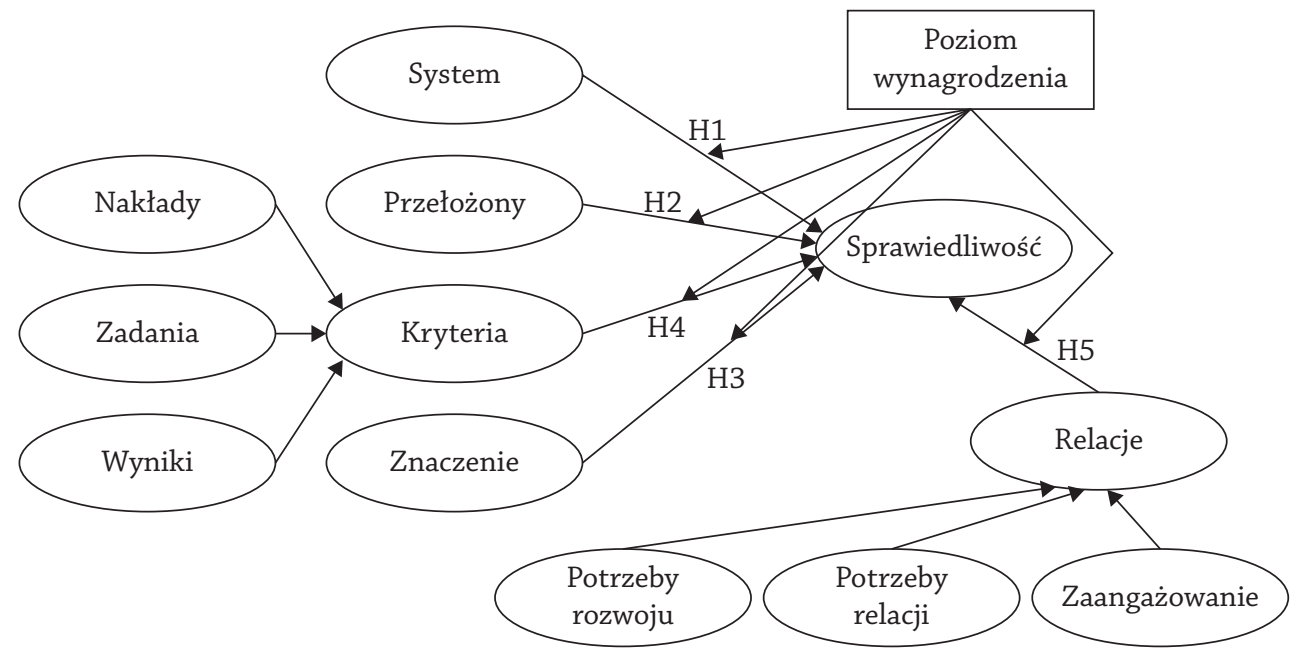

Źródło: opracowanie własne. 
„Sprawiedliwość” wynagradzania jest zmienną zależną w modelu. Jej poziom jest badany za pomocą trzech wskaźników empirycznych, obejmujących percepcję sprawiedliwości wynagrodzenia, adekwatności i satysfakcji. Związek między sprawiedliwością a adekwatnością wynagrodzenia w stosunku do wykonywanej pracy jest dość obszernie wyjaśniony w literaturze przedmiotu. Więcej kontrowersji dotyczy satysfakcji i sprawiedliwości wynagrodzenia. W literaturze przedmiotu można znaleźć pogląd, że istnieje możliwość wykorzystania tego samego instrumentarium do pomiaru postrzegania obu zjawisk (Scarpello, Carraher, 2008). Interpretując wyniki badania, należy jednak pamiętać, że stanowią one odrębne pojęcia. Satysfakcja wynika z zadowalającej oceny wynagrodzenia, pozwalającego na zaspokojenie potrzeb w oczekiwanym stopniu (Williams, McDaniel, Nguyen, 2006). Sprawiedliwość uwzględnia potrzeby i możliwości organizacji.

„System”, „przełożony”, „kryteria”, „znaczenie” i „relacje” są zmiennymi objaśniającymi.

"System” wynagradzania jest zmienną latentną. Formułują ją trzy wskaźniki empiryczne, obejmujące: percepcję jawności, jasności (oceny, czy system jest zrozumiały) i przekonanie o podobnych zarobkach na analogicznych stanowiskach.

"Przełożony” jest zmienną stworzoną na podstawie wskaźnika badającego przekonanie o dbałości przełożonego o odpowiednie wynagrodzenie dla swoich pracowników.

„Kryteria” są zmienną latentną endogeniczną. Tworzą ją zmienne określające przekonania o różnych wymiarach specyfiki pracy, wpływających na różnicowanie wynagrodzenia: doświadczenia pracownika i ilość poświęcanego czasu, trudności pracy i ilość obowiązków oraz efektów pracy.

„Znaczenie” jest zmienną stworzoną na podstawie wskaźnika badającego przekonanie o kluczowym znaczeniu wynagrodzenia w pracy.

"Relacje” są zmienną latentną endogeniczną. Składa się ona z: 1) zaangażowania, badanego uproszczoną metodą opracowaną przez M. Juchnowicz (2012), obejmującego: dumę i satysfakcję z pracy, poczucie bycia wykorzystywanym i chęć dzielenia się wiedzą, 2) „potrzeb relacji”, obejmujących wskaźniki badające przekonanie, że w pracy najważniejsza jest atmosfera i kontakt z ludźmi oraz pewność zatrudnienia oraz 3) „potrzeb rozwoju i niezależności”, formułowanych przez wskaźniki badające przekonanie, że w pracy najważniejsza jest możliwość rozwoju i awansu oraz niezależność i robienie tego, co się lubi.

Zmienne objaśniające: „system” i tworzące zmienną latetną endogenicznczą „relacje” skonstruowano w sposób formatywny, pozostałe, tj. „przełożony”, „kryteria" i „znaczenie" - w sposób reflektywny.

W testowanym modelu poziom wynagrodzenia jest moderatorem wpływu zmiennych objaśnianych na zmienną objaśniającą. Punktem wyjścia była analiza 
następujących przedziałów poziomów wynagrodzeń netto: poniżej 1400 PLN, 1401-2500 PLN, 2501-3500 PLN, 3501-5500 PLN, 5501-7500 PLN, 7501-10 000 PLN, powyżej 10000 PLN. Na podstawie wyników badań eksploracyjnych zakres został ograniczony do dwóch przedziałów: do 3500 PLN i powyżej tej kwoty.

\section{Wyniki badania}

Celem przeprowadzonego badania eksploracyjnego była weryfikacja, czy (i w jaki sposób) konstrukty zidentyfikowane na podstawie analizy literatury przedmiotu wpływają na ocenę sprawiedliwości wynagrodzenia. W tym celu zostało przeprowadzone badanie SEM-PLS.

Dane zostały zebrane w ramach badania przeprowadzonego w listopadzie 2017 r. na reprezentatywnej próbie pracujących Polaków $(N=1067)$ techniką telefoniczną CATI (Computer Assisted Telephone Interviewing). Dobór respondenta był losowy, przy jednoczesnym uwzględnieniu wymiarów: geograficznego (województwa), płci, wykształcenia i sektora. Struktura próby została określona dla poszczególnych wymiarów na podstawie aktualnych danych GUS.

\section{Ocena trafności modelu}

Używane miary charakteryzowały zadowalająca rzetelność mierzona za pomocą współczynnika $\alpha$ Cronbacha i współczynnika rzetelności łącznej (Composite Reliability, CR) oraz wysokie trafności zbieżna (oceniana za pomocą współczynnika przeciętnej wariancji wyjaśnionej, AVE) i różnicowa (spełnienie tzw. kryterium Fornella-Larckera). Wartość referencyjną dla współczynników $\alpha$ i CR przyjęto powyżej 0,7, dla AVE - powyżej 0,5. Statystyki dla miar wiarygodności pomiaru dla zmiennych reflektywnych dla modelu dotyczącego poziomu wynagrodzenia do 3500 PLN przedstawiono w tabeli 1, a dla modelu powyżej 3500 PLN - w tabeli 2.

Tabela 1. Statystyki miar wiarygodności dla modelu dotyczącego wynagrodzeń do 3500 PLN

\begin{tabular}{|c|c|c|c|c|c|c|c|c|c|c|c|}
\hline Konstrukt & 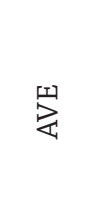 & : & 8 & 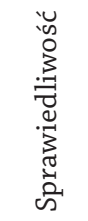 & 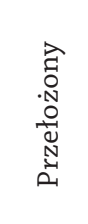 & 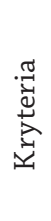 & $\begin{array}{l}\frac{\lambda}{\pi} \\
\frac{\pi}{\pi} \\
\frac{\pi}{z}\end{array}$ & $\begin{array}{l}\underset{\pi}{\tilde{J}} \\
\text { శ్ } \\
\text { N }\end{array}$ & $\begin{array}{l}\overrightarrow{\vec{y}} \\
\overrightarrow{\vec{z}} \\
\overrightarrow{3} \\
3\end{array}$ & 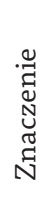 & $\frac{\stackrel{\tilde{g}}{\tilde{g}}}{\widetilde{\mathscr{d}}}$ \\
\hline Sprawiedliwość & 0,837 & 0,939 & 0,903 & 0,915 & & & & & & & \\
\hline Przełożony & 1,000 & 1,000 & 1,000 & 0,579 & 1,000 & & & & & & \\
\hline
\end{tabular}




\begin{tabular}{|c|c|c|c|c|c|c|c|c|c|c|c|}
\hline Konstrukt & 窔 & 艺 & $\gamma$ & 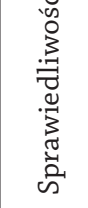 & 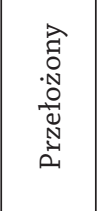 & 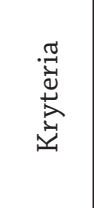 & 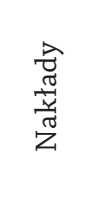 & $\begin{array}{l}\stackrel{\pi}{\Xi} \\
\text { J } \\
\text { J } \\
\text { N }\end{array}$ & 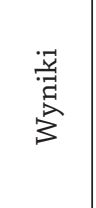 & 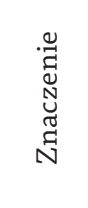 & 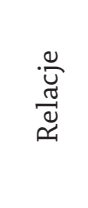 \\
\hline Kryteria & 0,487 & 0,823 & 0,729 & 0,162 & 0,085 & 0,698 & & & & & \\
\hline nakłady* & 0,585 & 0,738 & 0,292 & 0,196 & 0,131 & 0,750 & 0,765 & & & & \\
\hline zadania* & 0,779 & 0,876 & 0,717 & 0,118 & 0,061 & 0,897 & 0,479 & 0,883 & & & \\
\hline wyniki* & 1,000 & 1,000 & 1,000 & 0,078 & 0,008 & 0,725 & 0,377 & 0,512 & 1,000 & & \\
\hline Znaczenie & 1,000 & 1,000 & 1,000 & 0,081 & 0,042 & 0,204 & 0,112 & 0,206 & 0,153 & 1,000 & \\
\hline Relacje & 0,338 & 0,797 & 0,710 & 0,318 & 0,413 & 0,252 & 0,227 & 0,198 & 0,189 & 0,301 & 0,581 \\
\hline
\end{tabular}

* Itemy tworzą zmienną latentną „Kryteria”.

Źródło: opracowanie własne.

Tabela 2. Statystyki miar wiarygodności dla modelu dotyczącego wynagrodzeń powyżej 3500 PLN

\begin{tabular}{|c|c|c|c|c|c|c|c|c|c|c|c|}
\hline Konstrukt & 窔 & 货 & $\begin{array}{l}\frac{\pi}{3} \\
\frac{2}{2} \\
\frac{1}{4}\end{array}$ & 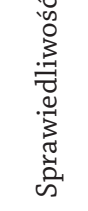 & 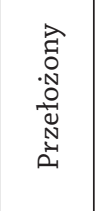 & 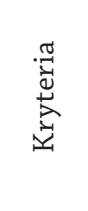 & 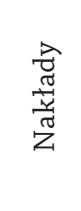 & 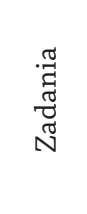 & $\begin{array}{l}\vec{y} \\
\overrightarrow{3} \\
\frac{5}{3}\end{array}$ & 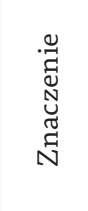 & 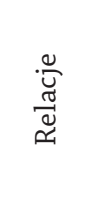 \\
\hline Sprawiedliwość & 0,784 & 0,916 & 0,904 & 0,885 & & & & & & & \\
\hline Przełożony & 1,000 & 1,000 & 1,000 & 0,522 & 1,000 & & & & & & \\
\hline Kryteria & 0,484 & 0,823 & 0,729 & 0,020 & 0,035 & 0,696 & & & & & \\
\hline nakłady* & 0,625 & 0,770 & 0,402 & 0,042 & 0,073 & 0,763 & 0,791 & & & & \\
\hline zadania* & 0,757 & 0,862 & 0,679 & 0,005 & 0,029 & 0,880 & 0,463 & 0,870 & & & \\
\hline wyniki* & 1,000 & 1,000 & 1,000 & 0,002 & $-0,033$ & 0,721 & 0,382 & 0,495 & 1,000 & & \\
\hline Znaczenie & 1,000 & 1,000 & 1,000 & 0,170 & 0,112 & 0,068 & 0,055 & 0,075 & 0,017 & 1,000 & \\
\hline Relacje & 0,308 & 0,768 & 0,661 & 0,404 & 0,390 & 0,232 & 0,173 & 0,196 & 0,187 & 0,245 & 0,555 \\
\hline
\end{tabular}

* Itemy tworzą zmienną latentną „Kryteria”.

Źródło: opracowanie własne.

Zakładając, że współczynnik $\alpha$ Cronbacha jest traktowany jako dolna granica prawdziwej rzetelności skali, a współczynnik rzetelności łącznej (CR) - jako jej górna granica, uzyskany poziom rzetelności można uznać za satysfakcjonujący. Trafność zbieżna dla większości konstruktów jest wysoka, a trafność różnicowa, oceniana na podstawie kryterium Fornella-Larckera, odpowiednia. 


\section{Analiza wyników}

Na podstawie analizy eksploracyjnej zidentyfikowano zróżnicowanie parametrów testowanego modelu w zależności od poziomu wynagrodzenia. Zmiana czynników wpływających na ocenę sprawiedliwości wynagrodzenia następowała przy wynagrodzeniu 3500 PLN. Wskaźniki ścieżkowe dla obu zidentyfikowanych wariantów modelu zostały przedstawione na rysunkach 2 i 3.

$\mathrm{Z}$ danych przedstawionych na rysunku 2 wynika, że w przypadku dochodów do 3500 PLN model badawczy wyjaśnia 37\% zmienności „sprawiedliwości” wynagrodzenia. Zaangażowanie oraz potrzeby rozwoju i relacji wyjaśniły $99,6 \%$ zmienności „relacji”, a przekonanie o różnicowaniu wynagrodzeń na podstawie nakładów, zadań i efektów pracy - 100\% zmienności „kryteriów”. Na podstawie badań eksploracyjnych ustalono, że „przełożony” wyjaśniał 19,9\% zmienności oceny „systemu” wynagradzania.

\section{Rysunek 2. Analizowany model ścieżkowy dla wynagrodzeń do 3500 PLN}

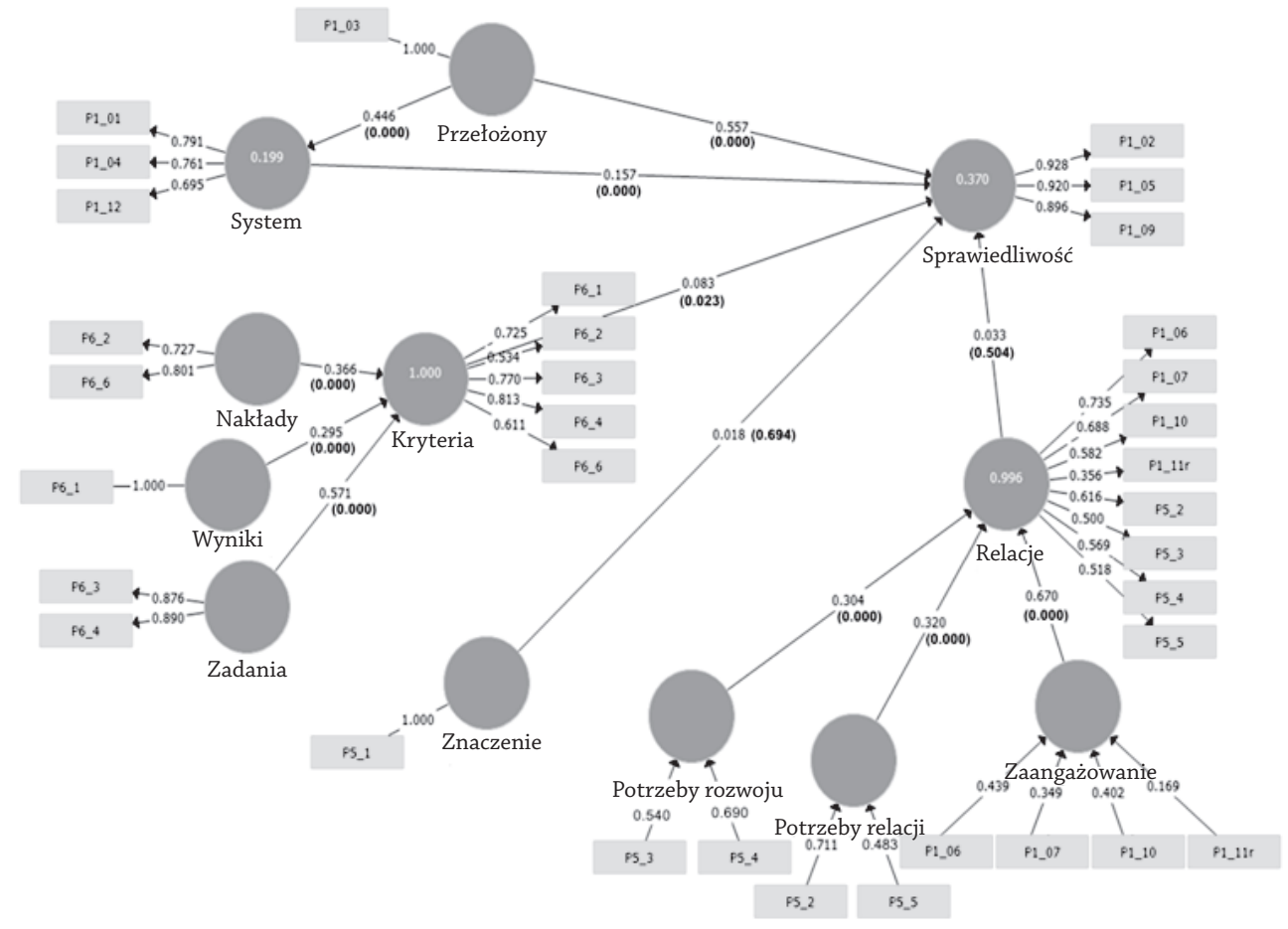

Źródło: opracowanie własne. 
Otrzymane wyniki wspierają hipotezy H1, H2 i H4. Natomiast z uwagi na brak istotności statystycznej nie udało się potwierdzić hipotez H3 i H5. Wśród osób zarabiających do 3500 PLN na ocenę sprawiedliwości wynagrodzenia najsilniej wpływa przełożony (H2). Oddziałuje zarówno bezpośrednio (współczynnik 0,557), jak i pośrednio poprzez ocenę systemu wynagradzania (współczynnik 0,446). Ocena systemu wynagradzania wpływa w mniejszym stopniu - współczynnik ścieżkowy wynosi 0,157. Najsłabszy wpływ mają przekonania dotyczące kryteriów, które powinny różnicować poziom wynagrodzenia - współczynnik ścieżkowy 0,083. Pozostałe czynniki testowane w modelu nie były istotne statystycznie. Dlatego na podstawie wyników badania nie można przyjąć hipotez o wpływie na ocenę sprawiedliwości osób zarabiających do 3500 PLN przekonań o kluczowym znaczeniu wynagradzania w pracy oraz znaczenia relacji w miejscu pracy.

Rysunek 3. Analizowany model ścieżkowy dla wynagrodzeń powyżej 3500 PLN

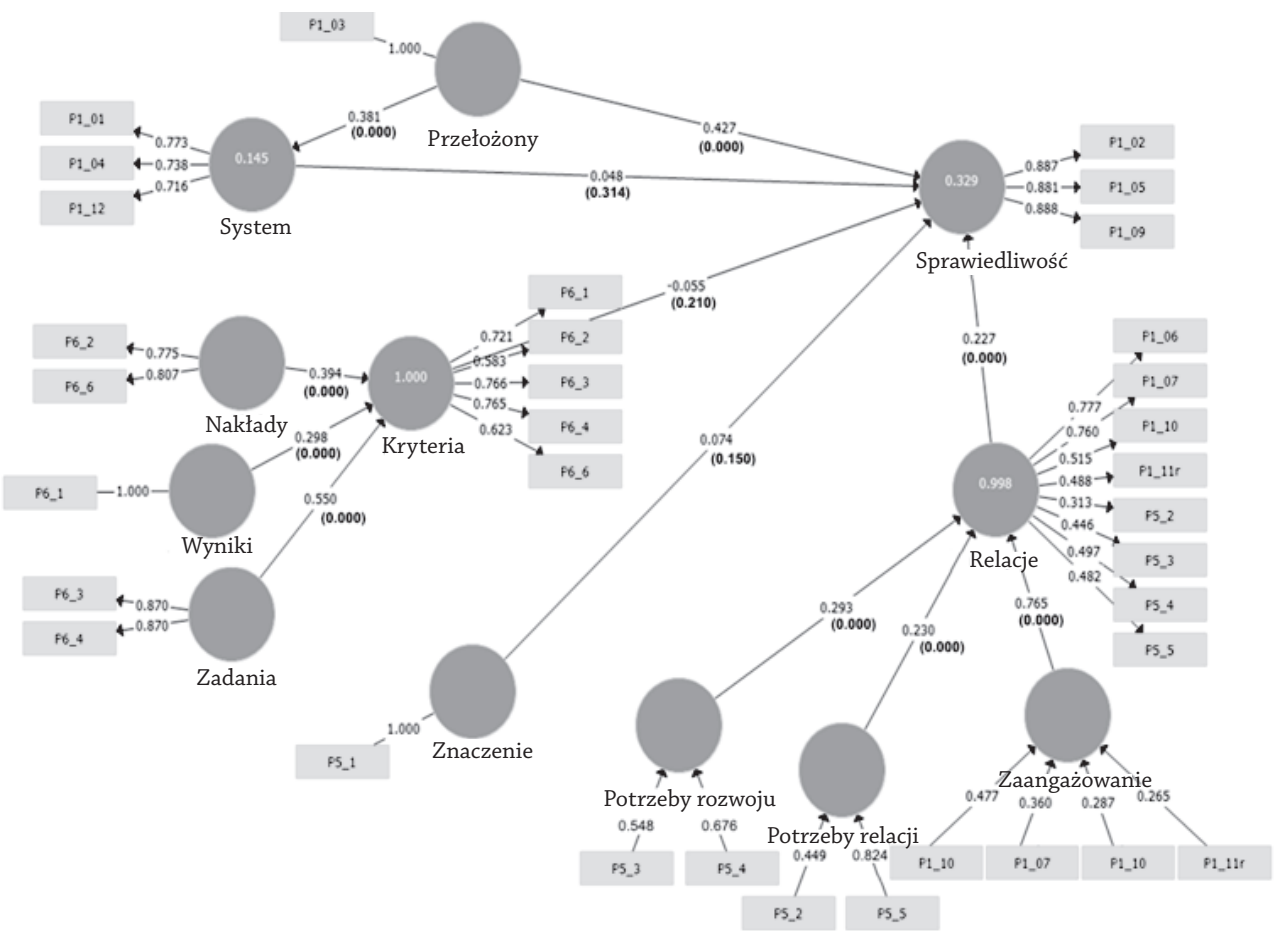

Źródło: opracowanie własne.

Na rysunku 3 przedstawiono wyniki dotyczące dochodów powyżej 3500 PLN. Z otrzymanych danych wynika, że model badawczy wyjaśnia 32,9\% zmienności 
„sprawiedliwości” wynagrodzenia. Zaangażowanie oraz potrzeby rozwoju i relacji wyjaśniły 99,8\% zmienności „relacji”, przekonanie o różnicowaniu wynagrodzeń na podstawie nakładów, zadań i efektów pracy - 100\% zmienności „kryteriów”, a „przełożony” - 14,5\% zmienności oceny „systemu” wynagradzania.

Na podstawie otrzymanych wyników można przyjąć hipotezy H2 i H5. Natomiast z uwagi na brak istotności statystycznej nie udało się potwierdzić hipotez H1, H3 i H4. Również w przypadku osób zarabiających powyżej 3500 PLN na ocenę sprawiedliwości wynagrodzenia najsilniej wpływa przełożony (H2) współczynnik 0,427. Drugim istotnym czynnikiem są relacje wewnętrzne - współczynniki ścieżkowy wynosi 0,227. Ocena systemu wynagradzania, przekonanie o kluczowym znaczeniu wynagradzania w pracy oraz o zasadności różnicowania wynagrodzeń na podstawie nakładów pracy, zadań i wyników nie były istotne statystycznie. Dlatego na podstawie wyników badania nie można przyjąć hipotez o ich wpływie na ocenę sprawiedliwości wynagrodzenia.

\section{Podsumowanie}

Przeprowadzone badania potwierdzają, że sprawiedliwość wynagradzania stanowi konstrukt wielowymiarowy. Czynniki wypływające na jej ocenę zmieniają się w zależności od poziomu płacy. Wspólnym kryterium - niezależnym od poziomu wynagrodzenia - jest troska przełożonego. W literaturze dotyczącej sprawiedliwości organizacyjnej rola przełożonego w kreowaniu sprawiedliwości wynagradzania jest stosunkowo nowa i mało zbadana. W publikacjach z zakresu zarządzania znacznie wyraźniej jest eksponowane znaczenie kształtu i parametrów systemu wynagradzania. Dodatkowo, reguła bezstronności - sformułowana na podstawie istniejącej w naukach o zarządzaniu definicji sprawiedliwości - wymagała zobiektywizowania procesów decyzyjnych, np. poprzez ograniczenie roli bezpośredniego przełożonego przy ustalaniu wynagrodzeń (Leventhal, 1980). Brak jego osobistego zaangażowania miał uchronić cały proces przed zarzutem faworyzowania. Tymczasem to właśnie od troski przełożonego o odpowiednie wynagrodzenia zależy w znacznym stopniu to, czy pracownik oceni je pozytywnie. Kluczowym wnioskiem dla nauki i praktyki jest konieczność zmiany podejścia do roli przełożonego w kształtowaniu wynagrodzenia - potrzebne jest zwłaszcza opracowanie instrumentarium, w którym rola ta zostanie przesunięta z marginesu do centrum.

Nie oznacza to jednak uzasadnienia dla kształtowania płac na postawie uznaniowych decyzji przełożonego. W przypadku pracowników zarabiających do 3500 PLN drugim istotnym czynnikiem oceny sprawiedliwości jest jawność, jasność i równość zasad wynagradzania. Oznacza to konieczność ustalania 
wynagrodzeń na podstawie zrozumiałych, przejrzystych i konsekwentnie aplikowanych reguł. Kryteria różnicujące powinny być zgodne z przekonaniami o wartości pracy i obejmować: doświadczenie pracownika i ilość poświęcanego czasu, trudność pracy oraz ilość obowiązków.

System wynagradzania i przekonania o kryteriach różnicujących poziom płac tracą swoją istotność przy zarobkach powyżej 3500 PLN. Kwota ta odpowiada w przybliżeniu płacy 4900 PLN brutto wypłacanej na podstawie umowy o pracę i jest zbliżona do przeciętnego wynagrodzenia publikowanego przez GUS (GUS, 2018). Z bardziej szczegółowych analiz GUS wynika, że zarobki poniżej średniej otrzymuje ok. 2/3 pracujących Polaków (GUS, 2017). Oznacza to, że kształt i kryteria systemu wynagradzania są ważne dla zdecydowanej większości zatrudnionych.

Z przeprowadzonych badań wynika, że osoby wynagradzane powyżej 3500 PLN, oceniając sprawiedliwość zarobków, biorą pod uwagę troskę przełożonego, własne zaangażowanie oraz potrzeby związane z rozwojem i niezależnością. Sukces organizacji zależy od gotowości kluczowych pracowników do wykorzystania własnego potencjału w realizacji zadań. Należy się spodziewać, że w tej grupie jest 1/3 najlepiej zarabiających Polaków. Ich chęć do zaangażowania się w funkcjonowanie organizacji zależy od skutecznego zastosowania kompleksowego instrumentarium. Badania potwierdziły, że: duma, satysfakcja, brak poczucia bycia wykorzystywanym, potrzeby rozwoju i pozytywnych relacji w miejscu pracy stanowią predykator postrzegania przez pracowników sprawiedliwości wynagradzania.

Podsumowując wyniki przeprowadzonych badań, można stwierdzić, że istniejąca w naukach o zarządzaniu definicja sprawiedliwości nie jest dostosowana do wymagań rzeczywistości. Temat sprawiedliwości jest jednocześnie ważny i niedostatecznie rozpoznany. Kontekstowość i sytuacyjność oceny sprawiedliwości wynagradzania wymagają pogłębionych badań prowadzonych na próbach o zdefiniowanej wcześniej charakterystyce. Sprawiedliwość wynagradzania jest kluczowym parametrem oceny najważniejszego systemu zarządzania ludźmi w organizacji, dlatego istnieje bezwzględna konieczność prowadzenia dalszych badań.

\section{Bibliografia}

Adams, S. (1965). Inequity in social Exchange. W: L. Berkowitz (red.), Advances in Experimental Social Psychology. New York: Academic Press.

Arystoteles (1956). Etyka nikomachejska. Warszawa: PWN.

Bies, R.J. (2001). Interactional in (justice): The sacred and the profane. W: J. Greenberg, R. Cropanzano (red.), Advances in Organizational Justice. Stanford: Stanford University. 
Card, D., Mas, A., Moretti, E., Saez, E. (2012). Inequality at work: The effect of peer salaries on job satisfaction. American Economic Review, 102(6), 2981-3003.

Colquitt, J.A., Conlon, D.E., Wesson, M.J., Porter, C., Ng, K.Y. (2001). Justice at the millennium: A meta-analytic review of 25 years of organizational justice research. Journal of Applied Psychology, 86, 425-445.

Cropanzano, R., Mitchell, M. (2005). Social exchange theory: An interdisciplinary review. Journal of Management, 31(6), 874-899.

Greenberg, J. (1993). The Social Side of Fairness: Interpersonal and Informational Classes of Organizational Justice. W: R. Cropanzano (red.), Justice in the Workplace: Approaching Fairness in Human Resource Management. Hillsdale, NJ: Lawrance Erlbaum Associates, 79-103.

GUS (2018). Komunikat w sprawie przeciętnego miesięcznego wynagrodzenia $w$ sektorze przedsiębiorstw bez wypłat nagród z zysku w maju 2018 roku. http://stat.gov. $\mathrm{pl} /$ sygnalne/komunikaty-i-obwieszczenia/lista-komunikatow-i-obwieszczen/ komunikat-w-sprawie-przecietnego-miesiecznego-wynagrodzenia-w-sektorz e-przedsiebiorstw-bez-wyplat-nagrod-z-zysku-w-maju-2018-roku,57,54.html (22.06.2018).

GUS (2017). Struktura wynagrodzeń według zawodów w październiku 2016 r. https:// stat.gov.pl/obszary-tematyczne/rynek-pracy/pracujacy-zatrudnieni-wynagrodzenia-koszty-pracy/struktura-wynagrodzen-wedlug-zawodow-w-pazdzierniku2016-r-,5,5.html (22.06.2018).

Hayek, F.A. (2011). Konstytucja wolności. Warszawa: Wydawnictwo Naukowe PWN.

Hughes, J.Ch., Rog, E. (2008). Talent management: A strategy for improving employee recruitment, retention and engagement within hospitality organizations. International Journal of Contemporary Hospitality Management, 20(7), 743-757.

Johnson, J. (2012). Prerceived fairness in compensation. Redmont: Economic Research Institute. https://www.erieri.com/PDF/PerceivedFairnessInComp.pdf (22.06.2018).

Juchnowicz, M. (2012). Zaangażowanie pracowników. Sposoby oceny i motywowania. Warszawa: PWE.

Juchnowicz, M., Kinowska, H. (2017). Strategie wynagrodzeń w różnych strategiach biznesowych. W: W.A. Sopińska, P. Wachowiak (red.), Wyzwania współczesnego zarzadzania strategicznego. Warszawa: Oficyna Wydawnicza SGH, 465-478.

Kinowska, H. (2009). The influence of chosen structural factors on employee engagement. Education of Economists and Managers, 13(3), 61-76.

Klimek, J. (2013). Godna praca, sprawiedliwa zapłata. Przedsiębiorstwo Przyszłości, 2(15), 70-79.

Leventhal, G.S. (1980). What should be done with equity theory? New approaches to the study of fairness in social relationships. W: K. Gergen, M. Greenberg, R. Willis (red.), Social Exchange: Advances in Theory and Research. New York: Springer-Verlag, 27-55. 
Mumford, K.A., Smith, P.N. (2012). Peer salaries and employee satisfaction in the workplace. IZA Discussion Paper No 6673. Bonn: Institute for the Study of Labor (IZA).

Petersen, B.K. (2014). Justice and culture in the perception of compensation fairness. Argumenta Oeconomica Cracoviensia, 11, 9-24.

Radzka, B. (2010). Zróżnicowanie wynagrodzeń w perspektywie sprawiedliwości dystrybutywnej. Zarzq̨dzanie Zasobami Ludzkimi, 2, 49-69.

Scarpello, V., Carraher, S.M. (2008). Are pay satisfaction and pay fairness the same construct? Baltic Journal of Management, 1(3), 23-39.

Shuck, B., Wollard, K. (2010). Employee engagement and HRD: A seminal review of the foundations. Human Resource Development Review, 9(1), 89-110.

Tekleab, A.G., Bartol, K.M., Liu, W. (2005). Is it pay levels or pay raises that matter to fairness and turnover? Journal of Organizational Behavior, 268, 899-921.

Thibaut, J., Walker, L. (1975). Procedural Justice: A Psychological Analysis. Hillsdale: Erlbaum.

Turek, D. (2011). Sprawiedliwość organizacyjna w przedsiębiorstwie. Kwartalnik Nauk o Przedsiębiorstwie, 1, 41-45.

Williams, M., McDaniel, M., Nguyen, N. (2006). A meta-analysis of the antecedents and consequences of pay level satisfaction. Journal of Applied Psychology, 91(2), 392-413.

Wratny, J. (1995). Koncepcja płacy sprawiedliwej a niektóre aktualne problemy prawa pracy i polityki płac w Polsce. Ethos, 4, 133-141.

Wratny, J. (2015). Prawo do wynagrodzenia za pracę w świetle zasad sprawiedliwości i równości. Annales Universitatis Mariae Curie-Skłodowska Lublin - Polonia, 62(2), 297-315.

Wu, X., Sturman, M.C., Wang, C. (2013). The Motivational Effects of Pay Fairness: A Longitudinal Study in Chinese Star-Level Hotels. Cornell Hospitality Quarterly, 542, 185-198.

\section{Summary}

\section{Differentiation in the Assessment of Compensation Justice According to Pay Levels}

Justice is a key parameter in assessing remuneration. Polish literature lacks empirical analyses of the essence of this construction. The main objective of the research was to identify the factors influencing the assessment of justice and their differentiation depending on the pay level. The results of the SEM-PLS analysis based on data collected on a representative sample of employed Poles showed that the type of factors changes with a monthly net salary of PLN 3,500. Below, the 
assessment of the fairness of remuneration is influenced by the concern of the superior, the compensation system and the belief in the rightness of remuneration differentiation based on inputs, tasks and results. Above this there are supervisor concerns and relationships in the workplace.

Keywords: compensation, justice of remuneration, pay level, employees' engagement, leadership in the organization

\section{Dr Hanna Kinowska}

Adiunkt w Instytucie Kapitału Ludzkiego w Szkole Głównej Handlowej w Warszawie, wykładowca, autorka wielu publikacji z zakresu zarządzania kapitałem ludzkim. Związana z praktyką, zrealizowała liczne projekty usprawniające zarządzanie kapitałem ludzkim, zwłaszcza w dziedzinach systemów wynagradzania i zaangażowania pracowników. 